\title{
A COMPARISON BETWEEN FAECAL STEROLS AND COLIFORM COUNTS IN THE INVESTIGATION OF SEWAGE CONTAMINATION IN SEDIMENTS
}

\author{
Renata Lima da Costa $^{(1, \#)}$ \& Renato S. Carreira ${ }^{(1, *)}$ \\ ${ }^{1}$ LaGOM/Departamento de Oceanografia da Universidade Estadual do Rio de Janeiro \\ (Rua São Francisco Xavier, 524, 20550-013 Rio de Janeiro, RJ, Brazil) \\ \# Master student - Graduate Program in Geochemistry/Fluminense Federal University \\ *corresponding author: carreira@uerj.br
}

\begin{abstract}
A B S T R A C T
In September 2002, nine sediment samples $(0-2 \mathrm{~cm})$ were collected from Botafogo Cove (southwestern part of Guanabara Bay) in order to compare the use of chemical (coprostanol) and biological markers (E. coli and total coliforms) in identifying faecal contamination. The values found (organic carbon -6.0 to $64.8 \mathrm{mg} \mathrm{g}^{-1}$; coprostanol -1.4 to $105 \mu \mathrm{g} \mathrm{g}^{-1} ;$ E. coli $-<30$ to $2400 \mathrm{NMP} / 10 \mathrm{~g}$ and total coliforms - 40 to $9300 \mathrm{NMP} / 10 \mathrm{~g}$ ) were similar to or even higher than those observed in other contaminated areas of Guanabara Bay. In stations close to the shoreline, both coprostanol concentration and bacteria count confirmed that domestic sewage had accumulated in the cove. Coprostanol concentrations were still relatively high in the stations furthest from contamination sources, although faecal material represented a smaller fraction of the total organic carbon originated by dilution in waters containing algae. Reduction was proportionately higher by virtue of the use of the colimetric assessment method. This result may be associated with the effect that environmental variables (light, salinity, temperature) may have on the survival of bacteria during transport and deposition of sewage particles. Consequently, based on these results, coprostanol may be considered the better indicator of the faecal contamination level in Botafogo Cove sediments.
\end{abstract}

\section{R ESUMO}

Em setembro de 2002, foram coletadas nove amostras de sedimento superficial $(0-2 \mathrm{~cm})$ na Enseada de Botafogo (sudoeste da Baía de Guanabara/RJ), a fim de comparar o uso de marcadores químicos (coprostanol) e biológicos (E. coli e coliformes totais) na identificação da contaminação fecal da região. Os resultados obtidos (carbono orgânico - 6,0 to $64,8 \mathrm{mg} \mathrm{g}^{-1}$; coprostanol - 1,4 to $105 \mu \mathrm{g} \mathrm{g}^{-1}$; E. coli $-<30$ to $2400 \mathrm{NMP} / 10 \mathrm{~g}$ e coliformes totais -40 to $9300 \mathrm{NMP} / 10 \mathrm{~g}$ ) foram iguais ou maiores aos observados em outras áreas contaminadas da Baía de Guanabara. Nas estações próximas à linha de costa, as concentrações de coprostanol e as contagens das bactérias confirmaram que o esgoto doméstico se acumulou no sedimento da enseada. As concentrações de coprostanol se mantiveram altas nas estações distantes das fontes de contaminação, porém o material fecal representou uma menor fração do carbono orgânico. Nessas mesmas estações, redução na contagem de colimetria foi proporcionalmente mais alta, provavelmente pela baixa sobrevivência das bactérias devido ao efeito de luz, salinidade e temperatura. durante o transporte e deposição das partículas de esgoto. Portanto, baseando-se nos resultados obtidos, o coprostanol foi um indicador mais adequado da contaminação fecal nos sedimentos da Enseada de Botafogo.

Descriptors: Guanabara bay; Brazil; domestic sewage; coprostanol; faecal indicator bacteria.

Descritores: Baía de Guanabara; Brasil; esgoto domésticos; coprostanol; bactérias indicadoras.

\section{INTRODUCTION}

Domestic sewage discharge in aquatic systems represents one of the major environmental problems resulting from human influence on nature. This is due to the difficulty involved in the disposal of the great volume of material produced, as well as the physical, geochemical and biological impact caused by such a procedure. Beyond the need to identify contamination sources, it is essential to understand the transport processes involved and discover where the material will finally be deposited in order to introduce measures capable of controlling and mitigating contamination by human waste (Takada et al., 1997; Seguel et al., 2001). 
The contamination of aquatic systems by sewage may be evaluated by microbiological and chemical markers, or indicators (Vivian, 1986; Takada \& Eganhouse, 1998). Microbiological markers, such as coliforms and streptococci bacteria, are widely used because the methods applied for their quantification are relatively simple and fast. In fact, in most countries, including Brazil, the water quality guidelines for primary and secondary contact are based on the number of these bacteria present. However, the use of bacteria as markers is controversial, because environmental factors such as salinity, temperature, rain, and effluent characteristics (chlorination, presence of other contaminants, etc) affect their survival. Consequently, their effectiveness as indicators of the presence of pathogenic organisms that might pose a threat to human health is greatly compromised (Isobe et al., 2002; Isobe et al., 2004; Noblet et al., 2004).

Although quantification of chemical markers is more laborious and expensive, they have higher source specificity and may persist longer than bacteria in the environment (Takada et al., 1997). Coprostanol $(5 \beta$-cholestan- $3 \beta$-ol), a faecal sterol produced in the digestive system of higher invertebrates by the microbial reduction of cholesterol (McCalley et al., 1981), has been successfully used as a marker for the assessment of sewage contamination in a variety of aquatic environments (Huang \& Meinschein, 1979; Brown \& Wade, 1984; Readman et al., 1986; Venkatesan \& Kaplan, 1990; Sherwin et al., 1993; Jeng \& Han, 1994; Chalaux et al., 1995; Mudge \& Bebianno, 1997; Jaffé et al., 2003).

Several studies conducted in temperate and cold areas based on water samples have shown a good correlation between counts of faecal indicator bacteria and coprostanol concentration (Leeming et al., 1996; Leeming \& Nichols, 1996; Isobe et al., 2002; Noblet et al., 2004 and references therein). On the other hand, significant deviations between the two markers have been observed in tropical regions due to specific environmental conditions (Isobe et al., 2004). As to sediment samples, studies are much more restricted. We have found only two studies comparing the distribution of coprostanol and faecal bacteria in sediments, and the relationship between the two indicators were highly dependent on local environmental conditions (Nichols et al., 1993).

Guanabara Bay (Fig. 1), located in the second largest urban area in Brazil, receives a significant load of raw sewage $\left(20-30 \mathrm{~m}^{3} \mathrm{~s}^{-1}\right)$, derived from a population of more than 7 million people living in its drainage basin (Feema, 1998). Of a total BOD load of 400 tons day ${ }^{-1}$ draining into the bay waters, 5 rivers alone in the northwestern sector, are responsible for 70 tons day $^{-1}$ of BOD (JICA, 1994).
The increasing accumulation of sewage in the sediments over the last 100 years in Guanabara Bay has recently been confirmed by the use of coprostanol as a marker (Carreira et al., 2004). In the present study, the sewage contamination in the southwestern part of the bay (Botafogo Cove) has been evaluated in terms of the distribution of both coprostanol (and other faecal sterols) and faecal coliform in superficial sediments. The specific objectives of the present study were to compare the level of sewage contamination in the cove with what was already know about Guanabara Bay in general and also to assess whether a biological marker may also be used for long-term (annual-decadal basis) indication of sewage accumulation in marine systems, for which the distribution of chemical markers (coprostanol) is customarily used.

\section{Materials And Methods}

Study Area and Sampling Procedures

Botafogo Cove is located in the southwestern part of Guanabara Bay (Fig. 1). On account of various landfills carried out since the $19^{\text {th }}$ century and as a result of intense shipping activities and domestic sewage discharge (most of which illegal), some of the beaches in the cove (Botafogo, Urca) present the worst bathing conditions within the municipality of Rio de Janeiro (Amador, 1997). In spite of its natural beauty and striking view handly any studies have been undertaken to evaluate the degree of water and sediment contamination of the cove.

Sediments were collected from 9 stations (Fig. 1) selected according to sediment granulometric characteristics and known sewage land sources. Sampling was performed in September/2002 using an Eckman-type dredge and only the top $2 \mathrm{~cm}$ of the sediment were sub-sampled. Samples for organic carbon and sterol determination were stored in precleaned aluminum boxes and kept frozen until analyzed in the laboratory. For the bacteriological analyses, the samples were transferred in the field to sterile glass bottles, placed on ice and processed within $8 \mathrm{~h}$ of collection.

\section{Analytical Methods}

\section{Total Organic Carbon and Total Nitrogen}

Total organic carbon (TOC) and total nitrogen $(\mathrm{TN})$ were determined for the sediment samples which were weighed precisely (2-5 mg) using a Carlo Erba EA 1110 elemental analyzer. Inorganic carbon was removed prior to analysis with hydrochloric acid $0.1 \mathrm{M}$, in accordance with Hedges \& 
Stern's (1984) method. Quantification was performed by using calibration curves and cystine as standard. Analytical precision was better than $3 \%$ for both parameters (based on 4 replicate analyses of the same sample) and accuracy was verified by analyzing a reference material (MESS-2, National Research Council of Canada).

\section{Sterols}

Analytical conditions for the sterol analyses were based on Carreira et al. (2004). Briefly, $5 \mathrm{~g}$ of dry sediment were extracted with $200 \mathrm{ml}$ of a mixture of dichloromethane and methanol $(2: 1 \mathrm{v} / \mathrm{v})$ for $20 \mathrm{~h}$. Before extraction, androstanol ( $5 \alpha$-androstan- $3 \beta$ ol) was added to the samples as surrogate. The bulk lipid extract was washed with a saturated solution of $\mathrm{NaCl}$. The non-polar (dichloromethane) fraction was isolated and combined with hexane, which was used to re-extract the polar (methanol/water) fraction. Following volume reduction by rotary evaporation, all trace of water was removed by overnight treatment with anhydrous sodium sulfate.

The bulk extract was saponified with a solution of methanol-KOH $20 \%$ in water, at $110^{\circ} \mathrm{C}$, for $2 \mathrm{~h}$. The sterols (and other non-saponified lipids) were recovered with n-hexane and further purified by column chromatography on silica gel by elution with $24 \mathrm{ml}$ of $10 \%$ methanol in dichloromethane. This fraction was concentrated by rotary evaporation and by a gentle stream of purified $\mathrm{N}_{2}$ and stored at $-20^{\circ} \mathrm{C}$ until analysis by gas chromatography-flame ionization detection (GC/FID) was undertaken.

Quantitative analyses of $1 \mu 1$ sample aliquots were performed using a Hewlett Packard 6890 gas

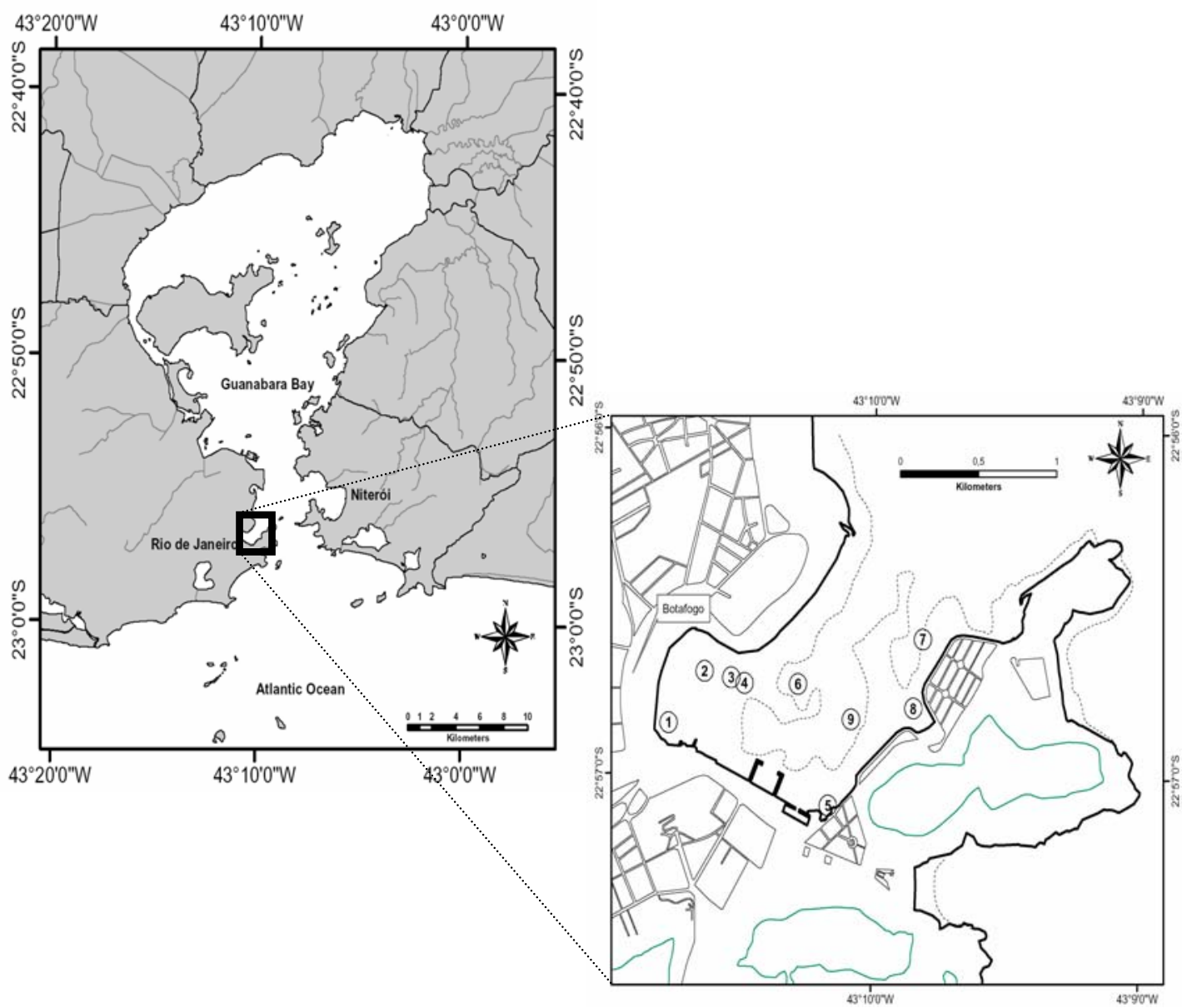

Fig. 1. Map of Guanabara bay showing Botafogo cove and the sampling stations. Dashed line on detailed figure of Botafogo cove indicate the 5-m water column depth. 
chromatograph in accordance with the conditions detailed in Carreira et al. (2004). Prior to injection, the sterols were derivatized by treatment with bistrimethylsilil trifluoroacetamida (BSTFA), $>99 \%$ pure, Aldrich $^{\circledR}$ at $60^{\circ} \mathrm{C}$ for $1 \mathrm{~h}$. Relative response factors were calculated for coprostanol, epicoprostanol, cholesterol and androstanol (surrogate) with respect to cholestane (internal standard). Compound identification was performed by retention time obtained by injection of authentic standards of the sterols considered in the present study.

Authentic standards of androstanol (internal standard), coprostanol, epicoprostanol and cholesterol were obtained from Sigma-Aldrich, Poole, UK. All standards were more than $98 \%$ pure. Standard solutions of all the sterols and the internal standard were analysed to confirm retention times and to check linearity of response. Relative response factors were calculated for the sterols considered in the present study with respect to the internal standard, androstanol. Throughout the study, sterol standard solutions ranging from 55 to $128 \mathrm{ng} \mu \mathrm{L}^{-1}$ were analysed daily to check the instrumental performance (response factors) and the chromatographic response (retention times, peak shape and resolution). Analyses of blanks were performed for each batch of samples, confirming the absence of significant contamination.

\section{Colimetrics}

The samples destined for microbiological analysis were kept frozen and analyzed on the same day on which they were collected. The procedure chosen for the total coliform and E. coli counts was the multiple tube technique in which sediment aliquots are submitted to decimal serial dilutions in peptonized water at $1 \%$. From each of these dilutions, equal aliquots were transferred to five series of three tubes (triplicates) containing the FLOR0CULT ${ }^{\circledR}$ lauryl sulphate culture broth and a gas collector tube. All tubes were incubated for 48 hours in an oven at a temperature of $36^{\circ} \mathrm{C}$, after which the positive tubes were identified. In the case of Eschericia coli, a positive count meant fluorescence under ultraviolet light of $365 \mathrm{~nm}$. With regard to total coliforms, the tubes in which gas had been formed were considered positive. Using the number of positive tubes in each dilution as a reference, the MPN (Most Probable Number) per 10 grams of sediment was determined, based on Hoskins statistical tables for three tubes.

\section{Results AND Discussion}

Distribution of Organic Carbon and Total Nitrogen in Sediments

The concentration of organic carbon $\left(\mathrm{C}_{\mathrm{org}}\right)$ in sediments from Botafogo Cove varied within one order of magnitude from $6.0 \mathrm{mg} \mathrm{g}^{-1}$ (station 4) to 64.8 $\mathrm{mg} \mathrm{g}^{-1}$ (station 5) (Table 1). These values were comparable to those found in other areas of Guanabara Bay with enriched organic matter sediments, such as the Icaraí and Jurujuba inlets, and areas to the north of the Rio-Niterói Bridge (28.3 to $55.4 \mathrm{mg} \mathrm{g-1;} \mathrm{Carreira}$ et al., 2002).

Total nitrogen $\left(\mathrm{N}_{\text {total }}\right)\left(0.6 \mathrm{mg} \mathrm{g}^{-1}\right.$ to $7.6 \mathrm{mg}$ $\mathrm{g}^{-1}$; Table 1$)$ was highly correlated to $\mathrm{C}_{\text {org }}(\mathrm{r}=0.98 ; \mathrm{P}$ $<0.01 ; \mathrm{n}=9$ ). The regression line between Corg and Ntotal (not shown) was close to the origin, which indicated that most of the sedimentary nitrogen was organic.

The cove was divided into two areas according to the distribution of $\mathrm{C}_{\text {org }}$, viz. stations 1 to 4 , located in the inner part of the cove with values below $16 \mathrm{mg} \mathrm{g}^{-1}$; and stations 5 to 9 with values above $30 \mathrm{mg} \mathrm{g}^{-1}$. As all the sediments were of similar mesh, different organic material supplies to the two areas generated varied concentrations. This distribution had not in fact, been anticipated, since stations 1 to 4 were located in an area of reduced water circulation, which night have been expected to present a greater accumulation of organic matter in the sediment.

The molar ratio $\mathrm{C} / \mathrm{N}$ (Table 1) helped determine the origin of the $\mathrm{C}_{\text {org }}$ in the sediments. In Figure 2 it was observed that higher values of $\mathrm{C}_{\text {org }}$ presented lower $\mathrm{C} / \mathrm{N}$ ratios (between 8 and 10). In stations with lower $\mathrm{C}_{\text {org }}$ concentrations the $\mathrm{C} / \mathrm{N}$ ratios were between 12 and 18 and a decreasing value gradient between station $1(\mathrm{C} / \mathrm{N}=17.5)$ and station 4 $(\mathrm{C} / \mathrm{N}=11.7)$ was found. Based on the typical $\mathrm{C} / \mathrm{N}$ ratios between autochthonous $(\mathrm{C} / \mathrm{N} \approx 4$ to 10$)$ and allochthonous $(\mathrm{C} / \mathrm{N} \geq 20)$ sources of organic material (Killops and Killops, 1993; Meyers, 1994), it became clear that stations 5 to 9 were influenced principally by the deposition of organic algal material produced in the water. This situation resulted from the nutrients available and the transparency of the water in this part of the cove. However, in stations 1 to 4, external organic carbon sources were predominant, apparently through the discharge of domestic sewage found from station 1 onwards, as will be seen below when the data on coprostanol are discussed.

\section{Coprostanol and Other Faecal Sterols in Sediments}

The mean concentration of coprostanol was $19.2 \pm 32.7 \mu \mathrm{g} \mathrm{g}^{-1}$, but the values ranged within two orders of magnitude (from $1.38 \mu^{-1} \mathrm{~g} \mathrm{~g}^{-1}$ at station 4 to $105 \mu \mathrm{g} \mathrm{g}^{-1}$ at station 1; Table 1). When compared to data already reported for Guanabara Bay (Carreira et al., 2004) and other estuaries throughout the world (see Readman et al., 2005), the values obtained in this present study characterize the sediments from Botafogo Cove as highly and chronically contaminated by sewage material. 
Table 1. Concentration of total organic carbon, total nitrogen, sterols and faecal indicator bacteria in sediments from Botafogo sound. The ratio coprostanol/cholesterol is also shown.

\begin{tabular}{|c|c|c|c|c|c|c|c|c|c|c|c|c|}
\hline Stations & $\begin{array}{l}\text { Lat. } \\
\text { (S) }\end{array}$ & $\begin{array}{l}\text { Long. } \\
\text { (W) }\end{array}$ & $\underset{\text { (mg.g-1) }}{\text { Corg }}$ & $\begin{array}{c}\text { Ntotal } \\
\text { (mg.g-1) }\end{array}$ & $\begin{array}{l}\mathrm{C} / \mathrm{N} \\
\text { ratio }\end{array}$ & $\begin{array}{c}\text { Coprostanol } \\
(\mu \mathrm{g} \mathrm{g}-1)\end{array}$ & $\begin{array}{l}\text { Coprostanol } \\
\left(\mu \mathrm{g} \mathrm{g}^{-1} \text { Corg) }\right.\end{array}$ & $\begin{array}{c}\text { Epicoprostanol } \\
\underset{\left(\mu \mathrm{g} \mathrm{g}^{-1}\right)}{ }\end{array}$ & $\begin{array}{c}\text { Cholesterol } \\
\left(\mu \mathrm{g} \mathrm{g}^{-1}\right)\end{array}$ & $\begin{array}{l}\text { Total Coliforms } \\
\text { (MPN/10g) }\end{array}$ & $\begin{array}{c}\text { E.coli } \\
\text { (MPN/10g) }\end{array}$ & $\begin{array}{c}\text { Coprostanol/ } \\
\text { Cholesterol }\end{array}$ \\
\hline 1 & $22^{\circ} 56^{\prime} 51^{\prime \prime}$ & $43^{\circ} 10^{\prime} 46^{\prime \prime}$ & 15.8 & 1.1 & 17.5 & 105.0 & 6688 & 6.77 & 18.4 & 9300 & 2400 & 5.74 \\
\hline 2 & $22^{\circ} 56^{\prime} 42^{\prime \prime}$ & $43^{\circ} 10^{\prime} 38^{\prime \prime}$ & 13.8 & 1.0 & 16.0 & 8.8 & 636 & 0.79 & 3.0 & 9300 & 930 & 2.93 \\
\hline 3 & $22^{\circ} 56^{\prime} 43^{\prime \prime}$ & $43^{\circ} 10^{\prime} 32^{\prime \prime}$ & 12.8 & 1.0 & 14.3 & 3.9 & 304 & 0.12 & 2.5 & 4300 & 700 & 1.55 \\
\hline 4 & $22^{\circ} 56^{\prime} 44^{\prime \prime}$ & $43^{\circ} 10^{\prime} 29^{\prime \prime}$ & 6.0 & 0.6 & 11.7 & 1.4 & 227 & 0.26 & 1.3 & 1500 & 930 & 1.04 \\
\hline 5 & $22^{\circ} 57^{\prime} 05^{\prime \prime}$ & $43^{\circ} 10^{\prime} 05^{\prime \prime}$ & 64.8 & 6.7 & 11.2 & 5.6 & 85 & 1.03 & 5.5 & 430 & 150 & 1.01 \\
\hline 6 & $22^{\circ} 56^{\prime} 44^{\prime \prime}$ & $43^{\circ} 10^{\prime} 17^{\prime \prime}$ & 63.9 & 7.6 & 9.8 & 22.0 & 344 & 3.75 & 14.1 & 2400 & 700 & 1.55 \\
\hline 7 & $22^{\circ} 56^{\prime} 36^{\prime \prime}$ & $43^{\circ} 09^{\prime} 49^{\prime \prime}$ & 32.3 & 4.5 & 8.3 & 5.7 & 175 & 1.04 & 6.0 & 40 & $<30$ & 0.95 \\
\hline 8 & $22^{\circ} 56^{\prime} 53^{\prime \prime}$ & $43^{\circ} 09^{\prime} 54^{\prime \prime}$ & 51.8 & 5.7 & 10.6 & 8.5 & 164 & 1.93 & 9.1 & 230 & 90 & 0.94 \\
\hline 9 & $22^{\circ} 56^{\prime} 50^{\prime \prime}$ & $43^{\circ} 10^{\prime} 05^{\prime \prime}$ & 54.3 & 7.3 & 8.6 & 12.4 & 229 & 2.84 & 13.1 & 90 & 40 & 0.94 \\
\hline
\end{tabular}

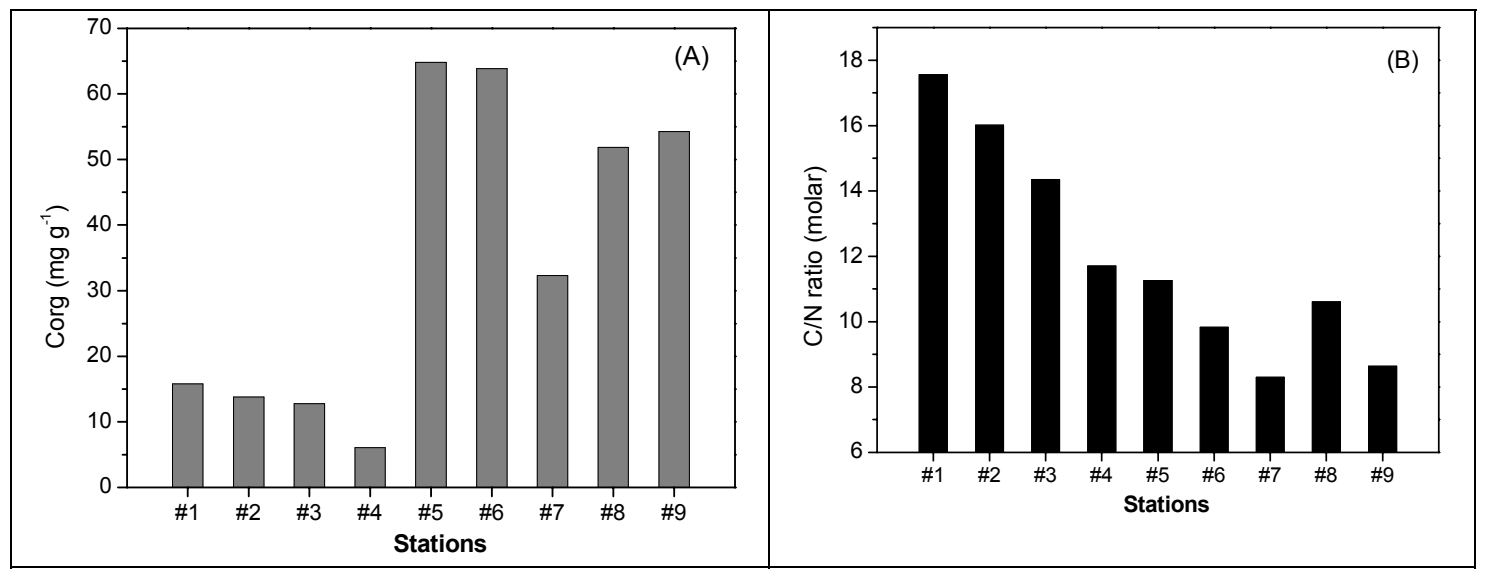

Fig. 2. Organic Carbon $\left(\mathrm{mg} \mathrm{g}^{-1}\right)$ and $\mathrm{C} / \mathrm{N}$ ratio (molar) in surficial sediments $(0-2 \mathrm{~cm})$

The distribution of coprostanol in the Botafogo Cove sediments was characterized by a high concentration at station 1 and a strong negative gradient down to station 4 (Fig. 3). The concentration of $105 \mu \mathrm{g} \mathrm{g}^{-1}$ at station 1 was only one order of magnitude lower than the values reported for dry sewage sludge (0.06 to $7.8 \mathrm{mg} \mathrm{g}^{-1}$; Takada \& Eganhouse, 1998). This reflected the discharge of raw sewage close to station 1 and the lack of efficient dispersion of sewage particles before its final deposition in the sediment.

The remaining stations $(5,6,7,8$ and 9$)$ exhibited moderate to high coprostanol concentrations (5.5 to $22.0 \mu \mathrm{g} \mathrm{g}^{-1}$; Table 1). This indicated the existence of sources of sewage other than that at station 1 . Besides, as stations 6,7 and 9 were located at greater water depths (>5 m; Fig. 3) and hence distant from the potential sources of sewage, the tidal currents might have played a significant role in the transport and accumulation of coprostanol at these sites.

The organic carbon-normalized concentration of coprostanol permitted the evaluation of the importance of sewage particles relative to that of the total sedimentary organic matter. The significant accumulation of sewage in the western part of the cove was confirmed (Fig. 4). On the other hand, the relatively high concentration of coprostanol at stations 5-9 (in a sediment dry-weight basis) represented a lesser of sewage contribution as a proportion of the total sedimentary organic matter, since these stations were affected by the deposition of a significant amount 


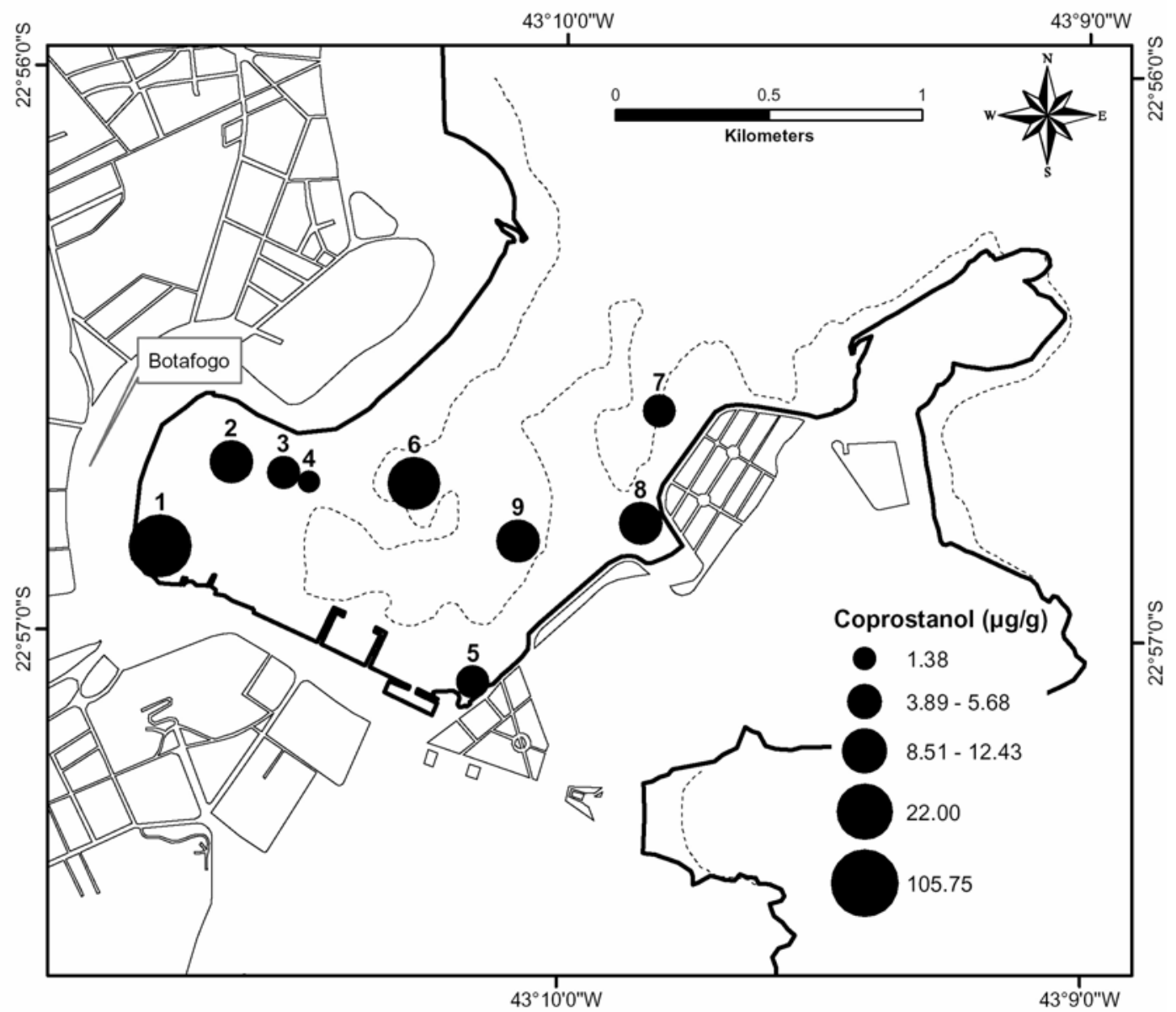

Fig. 3. Distribution of coprostanol (in $\mu \mathrm{g} \mathrm{g}^{-1}$ sediment dry wt.) in superficial sediments $(0-2 \mathrm{~cm})$.

of autochthonous organic matter (see previous discussion). This feature reflected the need to take the amount and type of sedimentary organic matter into consideration in order to establish a coprostanol-based level of sediment contamination by sewage.

Epicoprostanol is not a major human faecal sterol, but it can be produced from cholesterol during treatment of sewage or may be formed in situ under extreme anaerobic conditions (McCalley et al., 1981). The concentration of epicoprostanol obtained in this study $\left(2.05 \pm 2.13 \mu \mathrm{g} \mathrm{g}^{-1}\right)$ was higher than any previously reported for Guanabara Bay sediments $\left(0.28 \pm 0.46 \mu \mathrm{g} \mathrm{g}^{-1}\right.$; Carreira et al., 2004). Considering that the sewage receives no treatment before release, the values measured indicated the existence of favorable conditions in the sediment for the anaerobic transformation of coprostanol by bacteria, although this point needs to be further studied.
The reliability of faecal sterols as markers of sewage contamination may be enhanced by the consideration of different ratios between selected sterols (Takada \& Eganhouse, 1998). However, for Guanabara Bay it has been demonstrated that specific conditions, such as elevated temperatures and high algal productivity, limit the applicability of ratios usually considered in cold and temperate regions, with the exception of coprostanol/cholesterol ratios (Carreira et al., 2004). Values for the coprostanol to cholesterol ratio greater than 1 are usually considered an indication of chronic contamination of sediments by sewage (Quéméneur \& Marty, 1992; Quéméneur \& Marty, 1994; Takada et al., 1994; Fattore et al., 1996; Mudge \& Lintern, 1999). In this present study, values for this ratio consistent with the general distribution of sewage contamination as already discussed were found. Values as high as 5.7 at 
station 1 were measured in more heavily contaminated areas, while at stations 7,8 and 9 the coprostanol/cholesterol ratio values below 1 (0.94$0.95)$ indicated the overwhelming influence of plankton-derived cholesterol to that due to the total organic matter.

\section{Distribution of Faecal Indicator Bacteria}

The distribution of E.coli in Botafogo Cove sediments (Fig. 5) was characterized by a high count at station 1 (2400 NMP/10g, Table 1), intermediate values at stations $2,3,4$ and 6 and a significant decrease at stations 5, 7, 8 and 9 . Total coliforms were closely correlated with E.coli (r $=0.82 ; \mathrm{P}<0.01)$, although they varied significantly from one station to another. This may have been due to specific effects that environmental conditions produce with regard to a great number of species that make up the total coliforms (e.g., Escherichia, Enterobacter, Citrobacter e Klebsiell; Giammanco et al., 1992).

Although results may vary depending on the method used to determine E. coli and faecal coliforms, the highest counts of sewage bacteria markers obtained in this study were nevertheless lower than those cited by Nichols et al. (1993) for sediments contaminated by domestic sewage on the coast of Sydney, Australia. On the other hand, Kawakami (1999) found colimetric values on beaches improper for primary contact in the coastal region of the state of São Paulo similar to those found in Botafogo Cove.

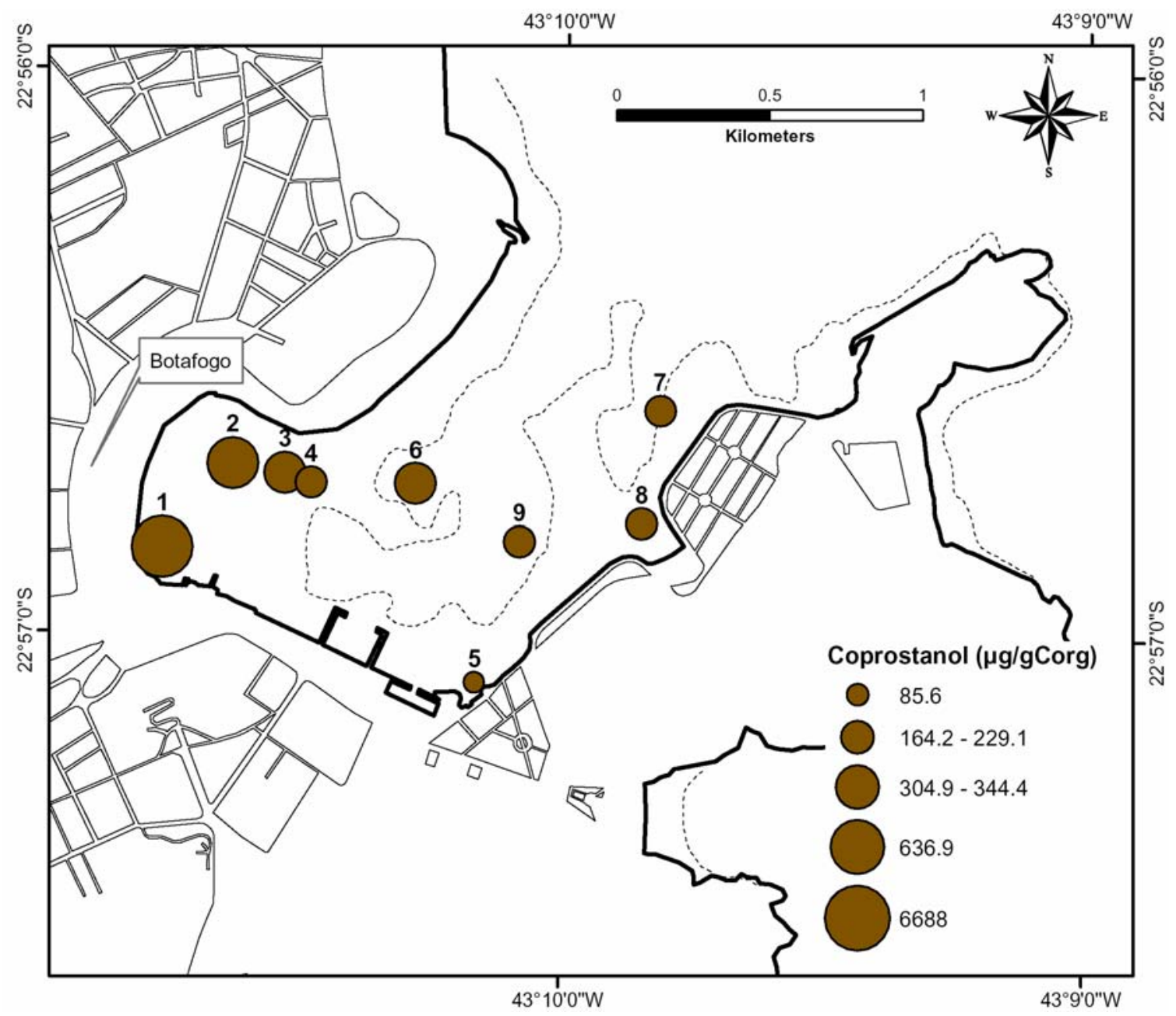

Fig. 4. Distribution of coprostanol $\left(\mu \mathrm{g} \mathrm{g}^{-1}\right.$ organic carbon) in superficial sediments $(0-2 \mathrm{~cm})$. 
The differences between faecal colifom densities in sediments located in temperate and tropical areas may be related to these organisms relative ability to survive at different temperatures.

Relationship of Coprostanol to Faecal Indicator Bacteria

The relationship between bacteria indicators and coprostanol in the water depends on environmental factors (Mudge \& Lintern, 1999; Noblet et al., 2004), but it is possible to develop a water quality criterion for bathing purposes based on coprostanol (Nichols et al., 1993; Leeming and Nichols, 1996; Isobe et al., 2004). According to Isobe et al. (2002), in tropical areas the limit for primary contact of $\sim 1000$ faecal coliforms per 100 $\mathrm{ml}$ (commonly adopted in several countries, including Brazil) corresponds to $30-100 \mathrm{ng} \mathrm{L}^{-1}$ of coprostanol.

There is no applicable legislation regarding sewage contamination in sediments. Comparative studies of coprostanol and colimetrics are, therefore, limited and the results inconclusive (Nichols et al., 1993).

The comparison between bacteria indicators and coprostanol in the present study confirms the division of the area studied (Figs $6 \mathrm{a}$ and $\mathrm{b}$ ), as discussed previously. At stations 5, 7, 8 and 9 the $E$. coli counts were low and would thus indicate lesser contamination of sediments by sewage particles. On the other hand, this result is not confirmed by the distribution of coprostanol, because the values of coprostanol at the same stations may be considered high ( $>5 \mu \mathrm{g} \mathrm{g}^{-1}$ or $>100 \mu \mathrm{g} \mathrm{g}^{-1} \mathrm{C}_{\text {org }}$ ) and reflect the

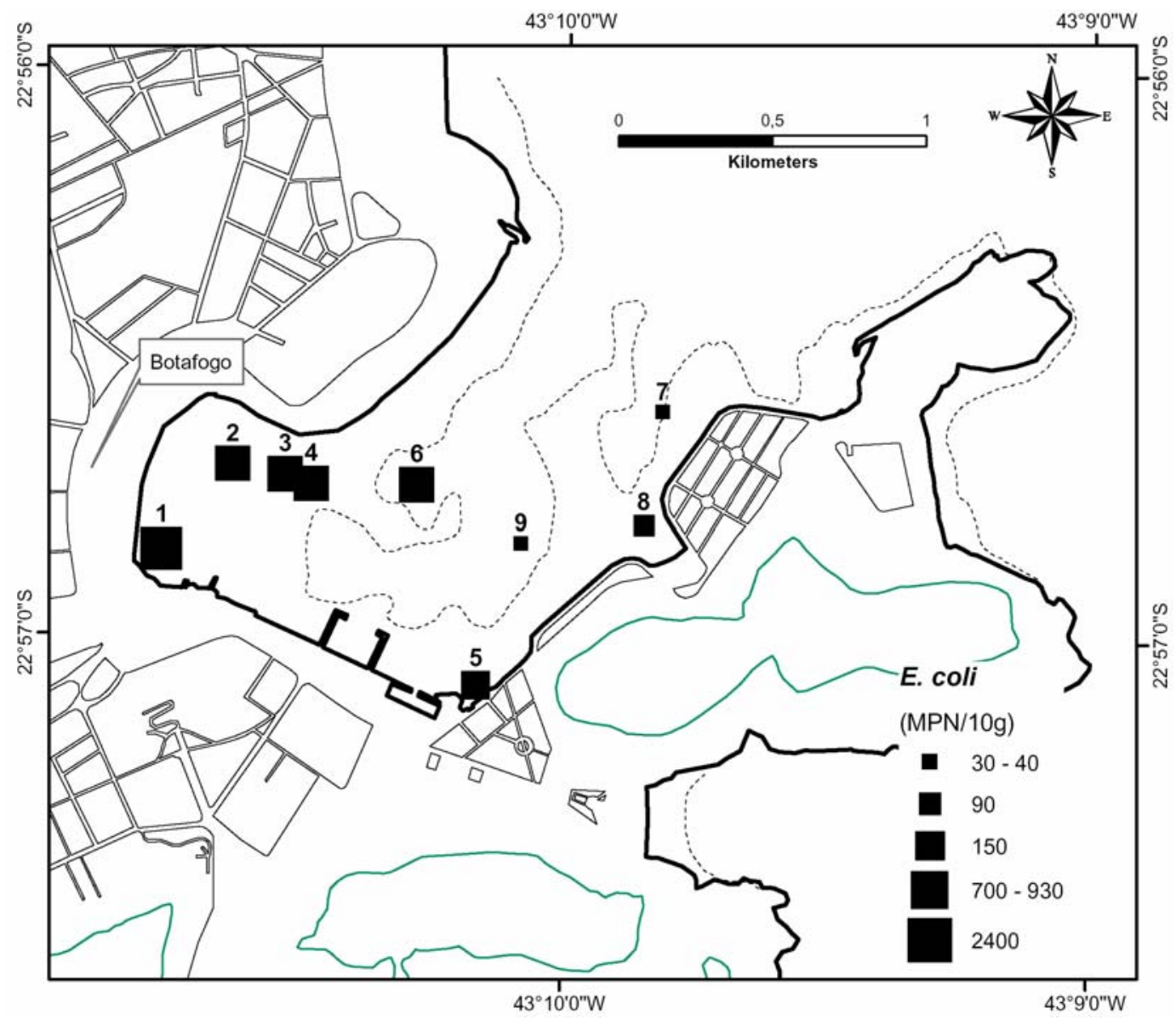

Fig. 5. Distribution of Escherichia coli (MPN/10g) in surficial sediments $(0-2 \mathrm{~cm})$. 

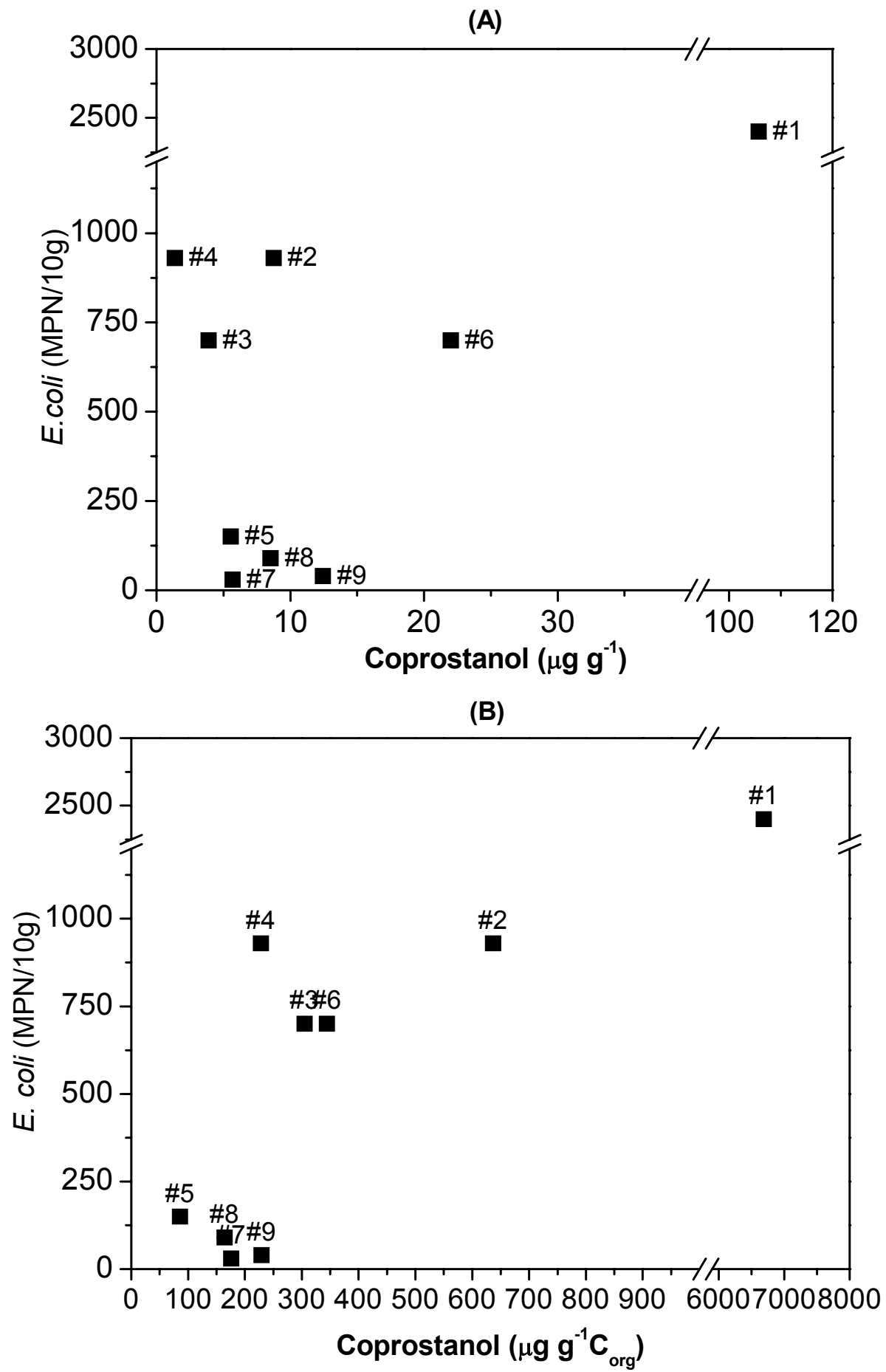

Fig. 6. Comparison of E.coli and coprostanol in dry weight basis (A) and in organic carbon-normalized concentrations (B). 
presence of sewage material in the sediments. This apparent inconsistency may be explained by the lower survival rate of bacteria in response to environmental factors (salinity, temperature and light), the effects of which are more severe in tropical areas. Thus, the transport of sewage particles in the water column would account for the decrease in the E.coli counts at those stations further removed from the terrestrial sources of sewage. Although it is also known that coprostanol may degrade under oxic conditions in the water column (Takada \& Eganhouse, 1998) this process is apparently less relevant than that influencing $E$. colis survival. In corroboration of this hypothesis, Nichols et al. (1993) found values as high as $\sim 1300$ for the faecal coliform/coprostanol ratio, in sediments impacted by sewage discharge in Sydney (Australia) whereas in the most contaminated site (station 1) in this present study this ratio was only 22 .

\section{Conclusions}

The main conclusions of the present study may be summarized as follows:

- Sediments in Botafogo Cove have coprostanol concentrations that characterize the area as highly contaminated by sewage material.

- Higher accumulation of sewage was observed in the inner part of the cove, associated with historical inputs of sewage.

- Stations located in the "external" part of the bay still have elevated coprostanol concentration, but the faecal material represents a lower proportion of the total organic matter. It will be necessary to study the water circulation in the region in greater detail so as better to evaluate the significance of this process for the transport and accumulation of contaminated particles to the stations farther from the terrestrial sources of sewage.

- $\quad$ The E. coli found in sediments was a reliable indicator of faecal contamination at stations near sewage sources, but is less significant than coprostanol at those stations farther removed from those sources, probably due to environmental factors (light, salinity, temperature).

\section{REFERENCES}

Amador, E. S., 1997. Baía de Guanabara e ecossistemas periféricos: homem e natureza. Rio de Janeiro, Reproart Gráfica e Editora Ltda. 539 p.

Brown, R. C. \& Wade, T. L., 1984. Sedimentary coprostanol and hydrocarbon distribution adjacent to a sewage outfall. Wat. Res., 18(5):621-632.
Carreira, R. S.;Wagener, A. L. R.; Readman, J. W.; Fileman, T. W.; Macko, S. \& Veiga, A. 2002. Changes in sedimentary organic carbon pool of a fertilized tropical estuary, Guanabara Bay, Brazil: an elemental, isotopic and molecular marker approach. Mar. Chem., 79(34):207-227.

Carreira, R. S.; Wagener, A. L. R. \& Readman, J. W., 2004. Sterols as markers of sewage contamination in a tropical urban estuary (Guanabara Bay, Brazil): space-time variations. Estuar. coast.Shelf Sci., 60(4):587-598.

Chalaux, N.; Takada, H. \& Bayona, J. M. 1995. Molecular markers in Tokyo bay sediments: sources and distribution. Mar. environ. Res., 40(1):77-92.

Fattore, E.; Benfenati, E.; Marelli, R.; Cools, E. \& Fanelli, R. 1996. Sterols in sediment samples from Venice lagoon, Italy. Chemosphere, 33(12):2383-2393.

Feema, 1998. Qualidade da água da Baía da Guanabara 1990 a 1997. Rio de Janeiro, Secretaria de Estado de Meio Ambiente, Fundação Estadual de Engenharia do Meio Ambiente.

Giammanco, G.; Pignato, S. \& Biondi, M., 1992. An enzymatic procedure for the confirmation of total coliforms and Escherichia coli enumeration from water. Zbl. Hyg., 193:99-105.

Hedges, J. I. \& Stern, J. H. 1984. Carbon and nitrogen determinations of carbonate-containing solids. Limnol. Oceanogr., 29(3):657-663.

Huang, W. Y. \& Meinschein, W. G. 1979. Sterols as ecological indicators. Geochim. Cosmochim. Acta, 43, 739-745.

Isobe, K. O.; Tarao, M.; Chiem, N. H.; Min, L.Y. \& Takada, H. 2004. Effect of environmental factors on the relationship between concentrations of coprostanol and fecal indicator bacteria in tropical (Mekong delta) and temperate (Tokyo) freshwaters. Appl. environ. Microbiol., 70(2):814-821.

Isobe, K. O.; Tarao, M.; Zakaria, M.; Chiem, N. H.; Minhle, Y. \& Takada, H. 2002. Quantitative application of fecal sterols using gas-chromatography - mass spectrometry to investigate fecal pollution in tropical waters: western Malaysia and Mekong Delta, Vietnam. Environ. Sci. Technol. 36:4497-4507.

Jaffé, R.; Gardinali, P. R.; Cai, Y.; Sudbuny, A.; Fernandez, A. \& Hay, B. 2003. Organic compounds and trace metals of anthropogenic origin in sediments from Montego Bay, Jamaica: assessment of sources and distribution pathways. Environ. Pollut. 123(2):291-299.

Jeng, W.-L. \& Han, B. C.1994. Sedimentary coprostanol in Kaohsiung harbor and theTan-Shui estuary, Taiwan. Mar. Pollut. Bull., 28(8):494-499.

JICA Japan International Cooperation Agency. 1994. The study on recuperation of the Guanabara Bay ecosystem. Tokyo, Kokusay, Kogyo Co. Ltd.

Killops, S. D. \& Killops, V. J. 1993. An introduction to organic geochemistry. Longman Geochemistry Series. Essex, UK, Longman Scientific \& Technical. 265 p.

Kawakami, S. K. \& Montone, R. C. 1999. Esteróides em sedimentos de Ubatuba e da Baía do Araça, São Paulo, como indicadores de contaminação por esgoto doméstico. VII Congresso Geoquímico dos Países de Língua Portuguesa. Porto Seguro, BA, Brasil. p. 102 104. 
Leeming, R.; Ball, A.; Ashbolt, N. \& Nichols, P. 1996. Using faecal sterols from humans and animals to distinguish faecal pollution in receiving waters. Water Res., 30(12):2893-2900

Leeming, R. \& Nichols, P. D. 1996. Concentrations of coprostanol that correspond to existing bacterial indicator guideline limits. Water Res., 30(12):2997-3006.

McCalley, D. V.; Cooke, M. \& Nickless, G. 1981. Effect of sewage treatment on faecal sterols. Water Res., 15:1019. 1025.

Meyers, P. A. 1994. Preservation of elemental and isotopic source identification of sedimentary organic matter. Chem. Geol., 114:289-302.

Mudge, S. M. \& Bebianno, M. J. 1997. Sewage contamination following an accidental spillage in the Ria Formosa, Portugal. Mar. Pollut. Bull., 34(3):163-170.

Mudge, S. M. \& Lintern, D. G. 1999. Comparison of sterol biomarkers for sewage with other measures in Victoria Harbor, B.C., Canada. Estuar. coast. Shelf Sci. 48:27-38.

Nichols, P. D.; Leeming, R.; Rayner, M. S.; Latham, V.; Ashbolt, N. J \& Turner, C. 1993. Comparison of abundance of the fecal sterol coprostanol and fecal bacterial groups in inner-shelf water and sediments near Sydney, Australia. J. Chromatogr., 643(1-2):189-195.

Noblet, J. A.; Young, D. L.; Zeng, E. Y. \& Ensari, S. 2004. Use of fecal sterois to infer the sources of fecal indicator bacteria in the lower Santa Ana river watershed, California: sewage is unlikely a significant source. Environ. Sci. Technol., 38:6002-6008.

Quéméneur, M. \& Marty, Y. 1992. Sewage influence in a macrotidal estuary: fatty acids and sterol distributions. Estuar. coast. Shelf Sci., 34:347-363.

Quéméneur, M. \& Marty, Y. 1994. Fatty acids and sterols in domestic wastewaters. Water Res., 28(5):1217-1226.

Readman, J. W.; Fillmann, G.; Tolosa, I.; Bartocci, J. \& Mee, L. D. 2005. The use of steroid markers to assess sewage contamination of the Black Sea. Mar. Pollut. Bull., 50(3):310.
Readman, J. W.; Preston, M. R. \& Mantoura, R. F. C. 1986. An integrated technique to quantify sewage, oil and $\mathrm{PAH}$ pollution in estuarine and coastal environments. Mar. Pollut. Bull., 17(7):298-308.

Seguel, C. G.; Mudge, S. M.; Salgado, C. S. \& Toledo, M., 2001. Tracing sewage in the marine environment: altered signatures in Concepción Bay, Chile. Water Res., 35(17):4166-4174.

Sherwin, M. R.; Van Vleet, E. S.; Fossato, V. U. \& Dolci, F. 1993. Coprostanol (5b-cholestan-3b-ol) in lagoonal sediments and mussels of Venice, Italy. Mar. Pollut. Bull., 26(9):501-507.

Takada, H. \& Eganhouse, R. P. 1998. Molecular markers of anthropogenic waste. In: Meyers, R. A. ed. Encyclopedia of Environmental Analysis and Remediation., New York, John Wiley \& Sons, Inc. p. 2883-2940.

Takada, H.; Farrington, J. W.; Botner, M. H.; Johnson, C. G. \& Tripp, B. W. 1994. Transport of sludge-derived organic pollutants to deep-sea sediments at Deep Water Dump Site 106. Environ. Sci. Technol., 28(6):10621072.

Takada, H. et al., 1997. Anthropogenic molecular markers: tools to identify the sources and transport pathways of pollutants. In: R.P. Eganhouse (Editor), Molecular markers in environmental geochemistry. ACS Symposium Series n. 671. Washington, American Chemical Society. p. 178-195.

Venkatesan, M. I. \& Kaplan, I. R., 1990. Sedimentary coprostanol as an index of sewage addition in Santa Monica Basin, southern California. Environ. Sci. Technol., 24:208-214.

Vivian, C. M. G. 1986. Tracers of sewage sludge in the marine environment: a review. Sci. Total Environ., 53:540 .

(Manuscript received 22 June 2005; revised 01 November 2005; accepted 29 November 2005) 